\title{
EFFECT OF COMPENSATION ON EMPLOYEE SATISFACTION AND EMPLOYEE PERFORMANCE
}

\author{
Anton Saman \\ Master of Management, Economics and Business Faculty, University of Mulawarman \\ Email: antonsamansh@gmail.com
}

\begin{abstract}
:
This study aims to determine the effect of compensation on job satisfaction and the effect of compensation on employee performance in the Mining Company. Data collected by interview, observation and literature study. The study is conducted against 51 employees with analisist the data using methods Partial Least Square (PLS). The results of this study reveal that compensation has a significant effect on job satisfaction, in addition, compensation also has a significant effect on employee performance.

Keywords: $\quad$ Compensation, satisfaction of work, the performance of employee
\end{abstract}

\section{Introduction}

Competition is the world of business between companies one by companies other very tight, things that require a company to have the advantage to compete in terms of quality of products, the products are produced, the cost and source of the power of human (HR) quality. HR better able to compete with the company of others and achieve the purpose of the company. However, in terms of achieving the objectives that there is also a failure, such as not achieve the objectives which have been assigned the company. By because it is, to be able to achieve the purpose of the company, the employee must be given a reward that is decent and fair in order to carry out their duties more excited and more good. It is concerning the compensation that given the company to the employees. Compensation such as a rewards are given to kar Javan to work much better. Compensation can increase and decrease the achievement of work (performance), the satisfaction of work, and motivation work employees (Kadarisman, 2012: 48). Providing compensation to employees must be reasonable and fair, because it can improve the ability of employees to increase work productivity, it is because employees can feel satisfaction in carrying out their work. Providing compensation to employees can motivate and provide job satisfaction.

According to the opinion of Mangkunagara (2013: 84) compensation that was given to the employees is very influential on the level of satisfaction of work and motivation to work, as well as the results of the work. Provide compensation in accordance with the type of work and employee job titles, then employees will feel satisfaction at work. A company should know the factors that could create the satisfaction of work for employees and can provide compensation as appropriate, so that could be achieved satisfaction of the work of employees who will be able to improve performance. Compensation is used as a tool to motivate employees in order to increase job satisfaction and employee performance. Performance that is good is to achieve the purpose of the company, so that an increase in the performance of highly needed by a company. Granting compensation that good can establish the performance of employees so much better in a company. The provision of compensation should be done in a fair and proper, so that employees can feel the satisfaction of work and result in performance that is good. One of the 
companies who want their employees to feel the satisfaction of work and improve its performance by way of giving compensation that is fair and right on Minning Company.

The purpose of the study is that to determine the effect of compensation to the satisfaction of the work as well as to determine the effect of compensation to the performance of the employee.

\section{Literature Review}

\section{Job Satisfaction}

Satisfaction work is a picture of the attitude of an employee either happy or not happy about rewards that come by, the work that is associated with his own, with his superiors, fellow employees, as well as environmental work. According to Robbins and Judge (2015: 46) explains that the satisfaction of work is as feeling positive about the job as a result of evaluation of its characteristics. Compensation is a reward that is given by the company to the employees on the work that it generates. According to Rivai and Sagala (2011: 741). According to Handoko (2014: 193) satisfaction of the work is a state of emotional which is fun or not fun where employees see work them. yatakan satisfaction of work (job satisfaction) is a response to effective or emotionally to various terms of job a person. According Wibowo (2014: 132) indicators of satisfaction of work, namely: Satisfaction on the job it 's own, the satisfaction on salary, satisfaction over the co- work, satisfaction on sale, satisfaction on conditions of employment.

\section{Performance}

Rivai and Sagala (2011: 548) define employee performance is a real behavior that is displayed by each person as an achievement of his work in accordance with their respective roles in the company. According to Mathis and Jackson (2011: 378) performance (perfomance), at basically is is what that is done or not done by employees. According Mangkunagara (2013: 67) performance is "the result of work by the quality and quantity of that achieved by an employee in carrying out their duties in accordance with sole responsibility that was given to him". According Torang (2013: 74) defines the performance is the quantity and quality of the results of the work of individuals or a group in the company in carrying out the task of principal and procedures , criteria and size that have been set or which apply within the company.

According to Anwar Prabu Mangkunagara (2009: 75) suggests that indicators of performance, namely: quality of work, quantity of work, the implementation of the duties, responsibilities responsibility. Factors that influence the achievement of performance, according to Mangkunegara (2000: 67) "is the ability factor (ability) and motivation factor (motivation)". Can be drawn the conclusion that the performance of the form of the quality and quantity of a result of work (outputs) of individual or group in an activity particular that caused by the ability of a natural or ability that is obtained from the process of learning and desire to excel . In addition, a person's motivation in carrying out work is a measure or benchmark for the maximum whether he works.

\section{Compensation}

Definition of compensation according to Dessler (2007), compensation of employees are all forms of payments or gifts that are given to employees and emerge from work them. In Basically there are two ways to make payments finance to employees, namely the payment directly and payments are not direct. According to Build (2012: 254) is one of the factors important and be attentive to the many organizations in the power of man that is qualified. According Suwanto and Priansa (2011: 219) states that compensation is a matter that is important, which is the encouragement or motivation main someone employee to work. According Kreitner and Kinicki 
(2014: 258) argues that compensation not only financial (salary and benefits), but also the opportunity of growth of personal and professional as well as environmental work motivates such recognition, the environmental work that is comfortable, the design work and balance. Compensation is something that is received by the employee as a substitute for the con t ribusi services of the services they are in the company, granting compensation is one of the implementation of the functions of Human Resource Management (HRM) which is associated with all kinds award on an individual as an exchange in doing the task organization by Veithzal, et al (2014: 541).

The indicator of compensation according to Simamora (2004: 445), namely: Salaries are fair, incentives are appropriate, allowances are in accordance with expectations, Fasolitas are adequate. The company's way to improve the quality of its employees is also for the company's growth by providing compensation. Each company has a compensation system that is different according to the vision, mission, and objectives. But from some opinions in general compensation has a specification that is almost the same. In research it will be discussed some of the specifications of compensation are given company is mine. to its employees.

According to some experts say that the compensation is divided into two kinds, "Compensation financially which both consist of compensation directly and compensation are not directly. Compensation directly that includes payment / repayment were obtained by a person / employee in the form of salary or wages, and incentives. Besides the compensation is not directly referred also to the benefits that all the rewards financially are not included in the compensation immediately, " Compensation of nonfinancial consist of work it themselves and the environment work where someone that works". System Compensation In a company definitely has a way of their own in granting compensation to the employee. Where systems are used adapted to the state of the environment the company and adapted to the system in other divisions that were on the compan 's or influenced by factors external companies such as neighborhood community around environmental work of companies.

\section{Effect of Compensation on Satisfaction}

Research which conducted Yaseen (013) with the title of the study " Effect of Compensation on Employee Satisfaction Factors-A Study of Doctor's Dissatisfaction in Punjab revealed that compensation impact significantly on the satisfaction of work . In addition to that, the research that is done Salisu et al. (2015) with the research title " The impact of compensation on the job satisfaction of the public sector construction workers of Nigeria State of Nigeria" also revealed that job satisfaction has a positive and significant effect on job satisfaction. Based on the research earlier that had been put forward, it can be arranged hypothetical study as follows:

H1: Compensation has a significant effect on job satisfaction.

\section{Effect of Compensation on Performance}

Research which conducted Darma \& Supriyanto (2017) with the title of the study "The effect of compensation on employee satisfaction and performance" revealed that the compensation effect significantly to the performance of the employee. In addition to that, the research that is done Wekesa \& Nyaroo (2013) with the title of the study "Effect of compensation on the performance of public secondary school teachers in Eldoret municipality Kenya" also revealed that the compensation effect significantly to the performance of the employee. Based on the research earlier that had been put forward, it can be arranged hypothetical study as follows:

$\mathrm{H} 2$ : Compensation has a significant effect on employee performance 
International Journal of Economics, Business and Accounting Research (IJEBAR)

Peer Reviewed - International Journal

Vol-4, Issue-1, 2020 (IJEBAR)

E-ISSN: 2614-1280 P-ISSN 2622-4771

https://jurnal.stie-aas.ac.id/index.php/IJEBAR

Conceptual framework

Figure 1

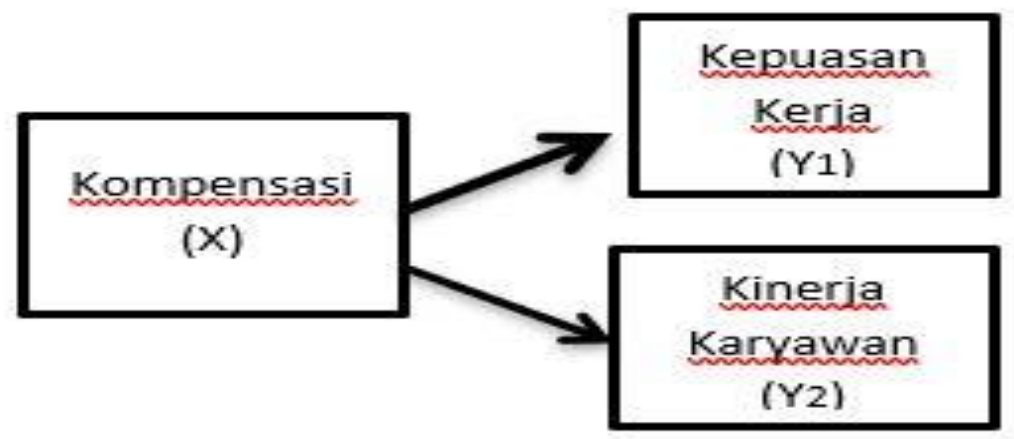

\section{Research Method}

The research is a kind of research explanations (explanatory research) with approach quantitative. In research it used the method of determining the sample by using the method of census of the whole employees of the Company mines amounted to 51 respondents. Because the number of research subjects numbered 51 people or in other words the population of 51 was less than 100 so this study used a census method where all the population was sampled. The population in the study have included a population limited that an employee. Analysis of the data in the study is using a model equation structural -based variance or component-based structural equation model, which is known by the Partial Least Square (PLS). According to Wold (Ghozali 2008: 4), PLS is a method of analysis that is powerful by because not based a lot of assumptions. Data does not have to be multivariate normally distributed, the sample does not have to be large. PLS is also a solution the best that can be done within the limited data that exist. Stages of analysis by using Partial Least Square (PLS) by (Lathan and Ghozali 2012: 47) is: conceptualization of a model, specify the model analysis algorithm, determines the methods of resampling, draw a diagram of the path, the evaluation models.

\section{Results and Discussion}

Table 1

The Relationship Between Variable Compensation, Job Satisfaction, and Employee Performance

\begin{tabular}{|l|c|c|c|}
\hline \multicolumn{1}{|c|}{$\begin{array}{c}\text { Relationship Between } \\
\text { Variables }\end{array}$} & $\begin{array}{c}\text { Path } \\
\text { coefficient }\end{array}$ & t-statistics & Information \\
\hline $\begin{array}{l}\text { Compensation (X) } \\
\text { Employee Performance } \\
(Y 2)\end{array}$ & 0.710 & 14,321 & Significance \\
\hline $\begin{array}{l}\text { Compensation (X) Job } \\
\text { Satisfaction (Y1) }\end{array}$ & 0.596 & 7,469 & Significance \\
\hline
\end{tabular}

Based on the table it, then it can be known influence between variable compensation to the satisfaction of the work which is indicated by the value of t-statistic 7.469>1,96. It is significant that the compensation effect exhibited significantly to the satisfaction of work. H1 received. 
Vol-4, Issue-1, 2020 (IJEBAR)

E-ISSN: 2614-1280 P-ISSN 2622-4771

https://jurnal.stie-aas.ac.id/index.php/IJEBAR

In addition, it can also be seen the effect of the compensation variable on employee performance as indicated by the value 14,321> 1.96. It is significant that the compensation effect significantly to the performance of employees. $\mathrm{H} 2$ received.

\section{Conclusion and Suggestion}

\section{Conclusion}

Based on the results and discussion, it can be drawn conclusions as follows: Compensation has the effect that a positive and significant to the satisfaction of the work of employees. It's means that $\mathrm{p}$ Increased compensation can improve the satisfaction of work of employees in the Company's mines.

Compensation has the effect that positively and significantly to the performance of the employee. It is demonstrated that $p$ Increased compensation can improve the performance of employees at the Company's mines.

\section{Suggestion}

To improve the performance of employees and address the decline in the performance of employees of the Company mines is recommended for more attention to the satisfaction of the work of employees, mainly provide compensation that is aligned with the factors of satisfaction and expectations of employees.

\section{References}

Bangun, Wilson. 2012. Manajemen Sumber Daya Manusia. Jakarta: Erlangga.

Darma, P. S., \& Supriyanto, A. S. (2017). The effect of compensation on satisfaction and employee performance. Management and Economics Journal (MEC-J), 1(1).

Dessler, Gary. 2007. Manajemen Sumber Daya Manusia. Edisi Kesepuluh. Jilid 2. Jakarta: PT. Indeks.

Handoko, T Hani. 2014. Manajemen Personalia \& Sumberdaya Manusia. Edisi Kedua. Cetakan Ke-21. Yogyakarta: BPFE YOGYAKARTA.

Kadarisman, M., 2012. Manajemen Kompensasi, Jakarta: PT Raja Grafindo Persada.

Kreitner, R., Kinicki, A., 2014. Perilaku Organisasi, Edisi 9, Buku 1, Jakarta : Salemba Empat.

Mangkunegara, Anwar Prabu. 2000. Manajemen Sumber Daya Manusia Perusahaan. Bandung: Cetakan Kedua Remaja Rosdakarya Offset. 2009. Evaluasi Kinerja SDM. Bandung: PT. Refika Aditama. 2013. Manajemen Sumber Daya Manusia Perusahaan. Bandung:

Remaja Rosdakarya.

Mathis, R.L., Jackson, J.H., 2011. Manajemen Sumber Daya Manusia, Edisi Sepuluh, Jakarta : Salemba Empat.

Rivai, V dan Sagala, E J. 2011. Manajemen Sumber Daya Manusia untuk Perusahaan. Jilid 2. Cetakan Ke-4. Jakarta: Rajagrafindo Persada.

Rivai, V., Mulyadi, D., 2011. Kepemimpinan dan Perilaku Organisasi, Edisi Ketiga, Jakarta : Rajawali Pers.

Robbins, Stephen P dan Timothy A Judge. 2015. Perilaku Organisasi, Edisi 16, Jakarta : Salemba Empat.

Salisu, J. B., Chinyio, E., \& Suresh, S. (2015). The impact of compensation on the job satisfaction of public sector construction workers of jigawa state of Nigeria. The Business \& Management Review, 6(4), 282.

Simamora, Henry. 2004. Manajemen Sumber Daya Manusia. Yogyakarta : YKPN. 
International Journal of Economics, Business and Accounting Research (IJEBAR)

Peer Reviewed - International Journal

Vol-4, Issue-1, 2020 (IJEBAR)

E-ISSN: 2614-1280 P-ISSN 2622-4771

https://jurnal.stie-aas.ac.id/index.php/IJEBAR

Suwatno; dan Priansa, D.J. 2011. Manajemen SDM Dalam Organisasi Publik dan Bisnis. Bandung: Alfabeta.

Torang, S. (2013). Organisasi \& manajemen; perilaku, struktur, budaya \& perubahan organisasi. Bandung: Penerbit Alfabeta.

Veithzal, Rivai dan Sagala, Ella Jauvani. 2014. Manajemen Sumber Daya Manusia untuk Perusahaan dari Teori ke Praktik. Jakarta: PT Raja Grafindo.

Wekesa, J. N., \& Nyaroo, S. (2013). Effect of compensation on performance of public secondary school teachers in eldoret municipality Kenya. International Journal of Scientific and Research Publications, 3(6), 1-4.

Wibowo, 2014. Perilaku dalam Organisasi, cetakan ke-1. Jakarta : PT Raja Grafindo Persada.

Yaseen, A. (2013). Effect of Compensation Factors on Employee Satisfaction-A Study of Doctor's Dissatisfaction in Punjab. International Journal of Human Resource Studies, 3(1), 142 